\title{
Complete sequence and organization of the mitochondrial genome of Cyclemys atripons (Testudines, Geoemydidae)
}

\author{
Li Zhang, Liu-wang Nie, Ying Zhang, Jin-long Rui and Yan-yun Zhang \\ Life Science College, Anhui Normal University, The Provincial Key Lab of the Conservation \\ and Exploitation Research of Biological Resources in Anhui, Wuhu, China.
}

\begin{abstract}
The Black Bridged Leaf Turtle, Cyclemys atripons (Testudines; Cryptodira; Geoemydidae), is a poorly known species within the genus Cyclemys. We determined the complete nucleotide sequence of the Cyclemys atripons mitochondrial genome (mtDNA) and found it to be 16,500 base pairs (bp) in length, with the genome organization, gene order and base composition being identical to that of the typical vertebrate. However, unlike for most turtle mtDNA so far reported, an extra base was not found in the NADH3 gene. The C. atripons control region of mtDNA was $981 \mathrm{bp}$ long. Comparisons with three other geoemydids showed that the $C$. atripons control region contained a highly variable region at the $3^{\prime}$ end composed of AT enriched tandem repeats containing a fifteen-unit 5'-A (AT) ${ }_{3}$ - $^{\prime}$ variable number of tandem repeats (VNTRs).
\end{abstract}

Key words: control region, Cyclemys atripons, mitochondrial genome, tandem repeats.

Received: March 19, 2007; Accepted: November 13, 2007.

Vertebrate mitochondrial (mt) DNA forms a double-stranded circular molecule of about $15-20 \mathrm{~kb}$ which generally contain 37 genes encoding 13 proteins, 22 tRNAs, 2 rRNAs and a major noncoding region bearing signals for mitochondrial replication and transcription (Wolstenholme, 1992). Due to its maternal inheritance and relative lack of recombination, the mitochondrial genome has been widely employed as a marker in vertebrate phylogenetic analyses, and have been often used in turtle science. Turtles are easily recognizable by the public, with approximately 270 species in the world (Iverson, 1992) and have been widely studied, with many earlier studies of mtDNA having concentrated on polymorphism analysis using restriction fragment length polymorphism (RFLP) and determining partial sequences (Lamb et al., 1989; 1994). However, the trend in more and more studies is to move to direct sequencing of the complete mtDNA (Peng et al., 2005, 2006; Parham et al., 2006). As of March 2007, complete mitochondrial genomes have been released from GenBank for only 17 turtle species, including 16 cryptodiran turtles and one side-necked turtle, which is far from being sufficient for reliable turtle studies.

The Black Bridged Leaf Turtle, Cyclemys atripons (Testudines; Cryptodira; Geoemydidae) is a poorly understood cryptodiran turtle species within the genus Cyclemys

Send correspondence to Prof. Liu-wang Nie. Life Science College, Anhui Normal University, 1 East Beijing Road, Wuhu, 241000, Anhui, China. E-mail: Iwnie@ @mail.ahnu.edu.cn.
(Guicking et al., 2002). Previously, only the cytochrome $b$ (Cyt $b$ ) gene of $C$. atripons mtDNA has been published (Spinks et al., 2004), clearly, further studies on this species are necessary. In our study, described in this paper, we sequenced and characterized the complete mitochondrial genome of $C$. atripons, which has laid the foundation for the further comparative analyses between $C$. atripons and other turtles.

In 2005 a C. atripons specimen was obtained from the suburbia of Longzhou city in the Chinese region of Guangxi, after natural death frozen at $-80{ }^{\circ} \mathrm{C}$ for preservation. Total DNA was extracted from the liver and muscle tissue using the proteinase $\mathrm{K}$ method (Sambrook and Russell, 2001) and kept at $-20{ }^{\circ} \mathrm{C}$ until needed for polymerase chain reaction (PCR) amplification.

Based on partial sequences reported by Spinks et al. (2004) and the similarity of mtDNA sequences of the painted turtle (Chrysemys picta; GenBank NC_002073) and Reeve's Turtle (Chinemys reevesii; GenBank AY676201) we designed 16 pairs of primers for PCR amplification (Table 1). The PCR was carried out in a total volume of $25 \mu \mathrm{L}$ containing $100 \mathrm{ng}$ of sample genomic DNA, $2.5 \mu \mathrm{L}$ of $10 \times$ Buffer (TaKaRa, Japan), $2 \mu \mathrm{L}$ of $2.5 \mathrm{~mol} \mathrm{~L}^{-1}$ of $\mathrm{MgCl}_{2}, 1.5 \mu \mathrm{L}$ of each dNTP, $0.25 \mu \mathrm{L}$ of each primer $\left(25 \mu \mathrm{mol} \mathrm{L}^{-1}\right)$ and 1 unit of Taq DNA polymerase (TaKaRa). The thermal cycles were $95{ }^{\circ} \mathrm{C}$ pre-denaturing for $2 \mathrm{~min}$, followed by 35 cycles of $94{ }^{\circ} \mathrm{C}$ for $40 \mathrm{~s}$, $51{ }^{\circ} \mathrm{C}$ to $58{ }^{\circ} \mathrm{C}$ for $45 \mathrm{~s}$ and $72{ }^{\circ} \mathrm{C}$ for $1 \mathrm{~min}$, plus a final ex- 
Table 1 - Polymerase chain reaction primers used in the determination of the complete mitochondrial genome of Cyclemys atripons.

\begin{tabular}{|c|c|c|c|}
\hline \multirow[t]{2}{*}{ Primer } & \multicolumn{2}{|c|}{ Primers $(\mathrm{Y}=\mathrm{C} / \mathrm{T}, \mathrm{R}=\mathrm{A} / \mathrm{g}, \mathrm{W}=\mathrm{A} / \mathrm{T}, \mathrm{M}=\mathrm{A} / \mathrm{C}, \mathrm{H}=\mathrm{A} / \mathrm{C} / \mathrm{T})$} & \multirow{2}{*}{$\begin{array}{l}\text { Approximate product } \\
\text { length (bp) }\end{array}$} \\
\hline & Upper light strand (L) 5' $\rightarrow 3^{\prime}$ sequence & Upper heavy strand (H) $5^{\prime} \rightarrow 3^{\prime}$ sequence & \\
\hline 1 & $\mathrm{~L} 1=\mathrm{AAGCATGGCACTGAAGTTGC}$ & H1 = TTTCATCTTTCCTTGCGGTAC & 1,116 \\
\hline 2 & L2 = AAAGCATTCAGCTTACACCTGA & H2 = AAGTTCCACAGGGTCTTCTCG & 1,065 \\
\hline 3 & L3 = TAATGCCTGCCCAGTGACA & H3 = TGATTCCGAGGGTTACTTC & 1,104 \\
\hline 4 & L4 = TCAGGGTGAGCTTCAAACTC & H4 GTAGTTGGGTTTGGTTTARTCC & 1,200 \\
\hline 5 & L5 = ACCTGACAAAAACTAGCCCCA & H5 = ACTATTCCTGCTCAGGCHCCG & 1,174 \\
\hline 6 & L6 = THTTCTCYACTAACCATAAAG & H6 = AAATCYTGCTATGATGGCGAA & 1,052 \\
\hline 7 & L7 = GCTATTCCCACAGGAGTAAAAG & H7 = GCTATCCTGTTTAGCTTCTATAG & 1,300 \\
\hline 8 & L8 = AAGTGGATGCARTCCCAGGACG & H8 = GTTATTAGTAGTGCTGCTGYTGC & 1,180 \\
\hline 9 & L9 = GCCTCTATCTACAAGAAAAC & H9 = GAARAATCGAATTGAGAATGG & 960 \\
\hline 10 & L10 = AGTACAAGTGACTTCCAATCA & H10 = TTTGRTTWCCTCATCGTGTG & 1,300 \\
\hline 11 & $\mathrm{~L} 11=$ GAACCAACCTCACGAAAACG & H11 = GCTGTTTTTACGGCTGTTTTTG & 1,200 \\
\hline 12 & L12 = AGGATAGAAGTAATCCAGTGG & H12 = TATCTTTCGRATGTCTTGTTC & 1,000 \\
\hline 13 & L13 = CATACACGCMTTCTTYAAAGC & H13 = CTAATAGTGATCCGAAGTTTCAT & 1,300 \\
\hline 14 & L14 = AACCACCGTTGTATTCAACTA & H14 = CAATCTTTGGTTTACAAGACC & 1,124 \\
\hline 15 & L15 = AGCAGCCTCCATTCTWTATTT & H15 = CAGTCTCATTGAGTYGGCAG & 800 \\
\hline 16 & L16 = TTTTACTCTCCCGTGCCCA & H16 = GTCACATTTTACGCCGATT & 980 \\
\hline
\end{tabular}

tension at $72{ }^{\circ} \mathrm{C}$ for $10 \mathrm{~min}$. The resultant PCR fragments were first resolved on $1 \%(\mathrm{w} / \mathrm{v})$ agarose gel (Promega, USA). After electrophoreses, gels were stained with ethidium bromide and bands were visualized under ultraviolet. Bands of intended size were excised and recovered with Gel Extract Purification Kit (TaKaRa, Japan). The cleaned PCR products were sequenced in both directions on an ABI3730 automated sequencer (Invitrogen Biotechnology). The sequences obtained from each sequencing reaction averaged $1000 \mathrm{bp}$ in length and each segment overlapped the next contig by roughly $150 \mathrm{bp}$. The whole mtDNA genome sequence was read at least twice.

Sequence data were analyzed with the EditSeq (DNASTAR) and ClustalX1.8 (Thompson et al., 1997) programs. The locations of protein-coding, rRNA and tRNA genes were identified by the tRNA Scan-SE1.21 and SQUEIN v. 5.35 programs, which were also used for the comparisons with the corresponding sequences from the other turtles cited above. The analysis of the control region sequence was carried out with the DNAsis and BioEdit programs. The resultant complete mitochondrial genome of $C$. atripons (16,500 bp) was deposited in GenBank under accession number EF067858.

The structural organization (Table 2) and gene order (Figure 1) of the complete $C$. atripons mitochondrial genome was identical that of other typical vertebrates, with the genome containing the following: 13 protein-coding genes, all of which except NADH6 being encoded on the $\mathrm{H}$-strand; 22 tRNA genes, 14 on the $\mathrm{H}$-strand and 8 on the L-strand; 2 rRNA genes, $12 \mathrm{~S}$ and $16 \mathrm{~S}$, both on the Hstrand; and one control region. There were few, or small, noncoding intergenic spacer nucleotides, with intervening sequences of $8 \mathrm{bp}$ between cytochrome c oxidase mitochondrial subunit II gene (COII) and tRNA ${ }^{\text {Lys }}$ plus $13 \mathrm{bp}$ between NADH4 and tRNA ${ }^{\text {His }}$ (Table 2). We found that the base composition of the major coding strand of $C$. atripons mtDNA was $\mathrm{A}=34.42 \%, \mathrm{G}=13.01 \%, \mathrm{C}=25.36 \%$ and $\mathrm{T}=27.20 \%$, demonstrating the low $\mathrm{G}$ and high $\mathrm{A}+\mathrm{T}$ bias seen in most other turtles (Pu et al., 2005; Peng et al., 2005, 2006). We also found that in C. atripons mtDNA three protein genes (COIII, NADH6 and Cyt $b$ ) have an incomplete stop codon such as $\mathrm{T}$, while the cytochrome c oxidase mitochondrial subunit I gene (COI) has GTG instead of ATG as a start codon. As in other vertebrate mitochondrial genomes, we found three instances of reading frame overlap, 10 nucleotides for ATP8 and ATP6, 7 for NADH4L and NADH4, and 5 for NADH5 and NADH6 (Table 2).

However, in $C$. atripons our analysis did not find the extra base usually found at a specific position in $N A D H 3$ of most other turtles (Mindell et al., 1998, 1999; Pu et al., 2005; Parham et al., 2006). Such an insertion in the NADH3 gene has been reported in most turtles with the exception of Pelodiscus sinensis and Kinosternon flavescens (Peng et al., 2005; Pu et al., 2005; Parham et al., 2006). It is generally thought the base could be related to a TAA stop codon frameshift prematurely terminating protein translation if not corrected by RNA editing or other mechanisms (Mindell et al., 1998, 1999). However, since the additional base is apparently absent from $C$. atripons more studies are needed to ascertain whether or not the extra base in NADH3 is a common characteristic of turtles or is specific to certain species and genera. 


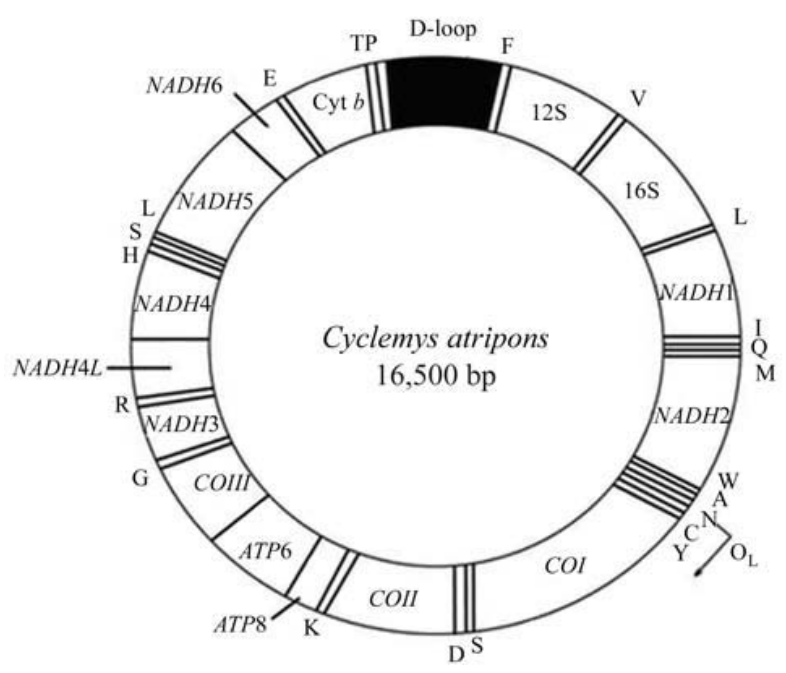

Figure 1 - Circular gene order of the mitochondrial genome of Cyclemys atripons. NADH1-6, and NADH4L: subunits 1-6 and 4L of nicotinamide adenine dinucleotide dehydrogenase; ATP 6 and 8 : subunits 6 and 8 of adenine triphosphatase; COI-III: cytochrome c oxidase subunits 1-3; Cyt $b$ : cytochrome b; 12S and 16S: 12 and 16S rRNA; D-loop: Control region. Each tRNA gene is identified by the single-letter amino acid code. $\mathrm{O}_{\mathrm{L}}$ represent the replication origin of L-strand.
We found that the $C$. atripons mitochondrial genome contained 22 tRNA genes, ranging in size from 66 nucleotides to 76 nucleotides (Table 2), interspersed between the rRNA and protein-coding genes, which is typical of the mtDNAs of other vertebrates. Most of the tRNA genes could be folded into the canonical cloverleaf secondary structure, the exception being the tRNA ${ }^{\text {Ser (AGY) }}$ gene which lacks the dihydrouridine arm (D arm). The length of the $C$. atripons 12S rRNA gene was 969 nucleotides and the 16S rRNA gene was 1,601 nucleotides long, these genes, as in other vertebrates, being separated by the tRNA ${ }^{\text {Val }}$ gene and positioned between the of tRNA ${ }^{\text {Phe }}$ and tRNA ${ }^{\text {Leu (UUR) }}$ genes (Table 2).

In the $C$. atripons mitochondrial DNA, we also found that the light-strand replication origin ( 31 nucleotides) was located between the tRNA ${ }^{\text {Asn }}$ and tRNA ${ }^{\text {Cys }}$ genes inside the WANCY tRNA gene cluster (Figure 1). This region has also been discovered in mtDNAs of all other cryptodiran turtles investigated (Pu et al., 2005; Peng et al., 2006), contrasting with its apparent disappearance from Pelomedusa subrufa (Zardoya and Meyer, 1998b). This C. atripons sequence may potentially fold into a stable stem-loop second-

Table 2 - Organization of the Cyclemys atripons mitochondrial genome (16,500 bp) ${ }^{*}$.

\begin{tabular}{|c|c|c|c|c|c|c|}
\hline \multirow[t]{2}{*}{ Gene/elements } & \multirow{2}{*}{$\begin{array}{l}\text { Position } \\
\text { from-to }\end{array}$} & \multirow{2}{*}{$\begin{array}{l}\text { Size } \\
(\mathrm{bp})\end{array}$} & \multirow{2}{*}{$\begin{array}{l}\text { Strand } \\
\text { (sense) }\end{array}$} & \multicolumn{2}{|c|}{ Codon } & \multirow{2}{*}{$\begin{array}{c}\text { 5' intergenic } \\
\text { space }^{a}\end{array}$} \\
\hline & & & & Start & Stop & \\
\hline tRNA $^{\text {Phe }}$ & $1-70$ & 70 & $\mathrm{H}$ & & & 0 \\
\hline 12S rRNA & $71-1,035$ & 965 & $\mathrm{H}$ & & & 0 \\
\hline $\mathrm{tRNA}^{\mathrm{Val}}$ & $1,036-1,105$ & 70 & $\mathrm{H}$ & & & 0 \\
\hline $16 \mathrm{~S}$ rRNA & $1,106-2,701$ & 1,596 & $\mathrm{H}$ & & & 0 \\
\hline tRNA $^{\text {Leu (UUR) }}$ & $2,702-2,777$ & 76 & $\mathrm{H}$ & & & 0 \\
\hline $\mathrm{NADHI}$ & $2,778-3,749$ & 972 & $\mathrm{H}$ & ATG & TAG & -1 \\
\hline $\mathrm{tRNA}^{\mathrm{Ile}}$ & $3,749-3,818$ & 70 & $\mathrm{H}$ & & & -1 \\
\hline $\mathrm{tRNA}^{\mathrm{Gln}}$ & $3,818-3,888$ & 71 & $\mathrm{~L}$ & & & -1 \\
\hline $\mathrm{tRNA}^{\mathrm{Met}}$ & $3,888-3,956$ & 69 & $\mathrm{H}$ & & & 0 \\
\hline $\mathrm{NADH} 2$ & $3,957-4,997$ & 1,041 & $\mathrm{H}$ & ATG & TAG & -2 \\
\hline $\mathrm{tRNA}^{\mathrm{Trp}}$ & $4,996-5,071$ & 76 & $\mathrm{H}$ & & & 1 \\
\hline $\mathrm{tRNA}^{\mathrm{Ala}}$ & $5,073-5,141$ & 69 & $\mathrm{~L}$ & & & 1 \\
\hline $\mathrm{tRNA}^{\mathrm{Asn}}$ & $5,143-5,215$ & 73 & $\mathrm{~L}$ & & & 1 \\
\hline $\mathrm{O}_{\mathrm{L}}$ & $5,217-5,246$ & 30 & - & & & -3 \\
\hline $\mathrm{tRNA}^{\mathrm{Cys}}$ & $5,244-5,309$ & 66 & $\mathrm{~L}$ & & & 0 \\
\hline $\mathrm{tRNA}^{\mathrm{Tyr}}$ & $5,310-5,380$ & 71 & $\mathrm{~L}$ & & & 1 \\
\hline $\mathrm{COI}$ & $5,382-6,929$ & 1,548 & $\mathrm{H}$ & GTG & AGG & -9 \\
\hline $\mathrm{tRNA}^{\mathrm{Ser}(\mathrm{UCN})}$ & $6,921-6,991$ & 71 & $\mathrm{~L}$ & & & 2 \\
\hline $\mathrm{tRNA}^{\mathrm{Asp}}$ & $6,994-7,063$ & 70 & $\mathrm{H}$ & & & 0 \\
\hline COII & $7,064-7,750$ & 687 & $\mathrm{H}$ & ATG & TAG & 8 \\
\hline tRNA $^{\text {Lys }}$ & $7,759-7,831$ & 73 & $\mathrm{H}$ & & & 1 \\
\hline ATP8 & $7,833-8,000$ & 168 & $\mathrm{H}$ & ATG & TAA & -10 \\
\hline ATP6 & $7,991-8,674$ & 684 & $\mathrm{H}$ & ATG & TAA & -1 \\
\hline COIII & $8,674-9,457$ & 784 & $\mathrm{H}$ & ATG & $\mathrm{T}$ & 0 \\
\hline $\mathrm{tRNA}^{\mathrm{Gly}}$ & $9,458-9,526$ & 69 & $\mathrm{H}$ & & & 0 \\
\hline
\end{tabular}


Table 2 (cont.)

\begin{tabular}{|c|c|c|c|c|c|c|}
\hline \multirow[t]{2}{*}{ Gene/elements } & \multirow{2}{*}{$\begin{array}{l}\text { Position } \\
\text { from-to }\end{array}$} & \multirow{2}{*}{$\begin{array}{l}\text { Size } \\
\text { (bp) }\end{array}$} & \multirow{2}{*}{$\begin{array}{l}\text { Strand } \\
\text { (sense) }\end{array}$} & \multicolumn{2}{|c|}{ Codon } & \multirow{2}{*}{$\begin{array}{c}\text { 5' intergenic } \\
\text { space }^{a}\end{array}$} \\
\hline & & & & Start & Stop & \\
\hline NADH3 & $9,527-9,877$ & 351 & $\mathrm{H}$ & ATG & TAG & -2 \\
\hline $\mathrm{tRNA}^{\mathrm{Arg}}$ & $9,876-9,945$ & 70 & $\mathrm{H}$ & & & 0 \\
\hline NADH4L & $9,946-10,245$ & 300 & $\mathrm{H}$ & ATG & TAA & -7 \\
\hline $\mathrm{NADH} 4$ & $10,239-11,615$ & 1,377 & $\mathrm{H}$ & ATG & TAA & 13 \\
\hline $\mathrm{tRNA}^{\mathrm{His}}$ & $11,629-11,698$ & 70 & $\mathrm{H}$ & & & 0 \\
\hline tRNA $^{\text {Ser(AGY) }}$ & $11,699-11,764$ & 66 & $\mathrm{H}$ & & & -1 \\
\hline tRNA $^{\text {Leu(CUN) }}$ & $11,764-11,835$ & 72 & $\mathrm{H}$ & & & 0 \\
\hline NADH5 & $11,836-13,641$ & 1,806 & $\mathrm{H}$ & ATG & TAA & -5 \\
\hline NADH6 & $13,637-14,161$ & 525 & $\mathrm{~L}$ & ATG & $\mathrm{T}$ & 0 \\
\hline $\mathrm{tRNA}^{\mathrm{Glu}}$ & $14,162-14,229$ & 68 & $\mathrm{~L}$ & & & 4 \\
\hline Cyt $b$ & $14,234-15,377$ & 1,144 & $\mathrm{H}$ & ATG & $\mathrm{T}$ & 0 \\
\hline $\mathrm{tRNA}^{\mathrm{Thr}}$ & $15,378-15,449$ & 72 & $\mathrm{H}$ & & & 1 \\
\hline tRNA $^{\text {Pro }}$ & $15,451-15,519$ & 69 & $\mathrm{~L}$ & & & 0 \\
\hline Control region & $15,520-16,500$ & 981 & - & & & \\
\hline
\end{tabular}

*NADH1-6 and NADH4L: NADH dehydrogenase subunits 1-6 and 4L; COI-III: cytochrome c oxidase subunits I-III; ATP6 and ATP8: ATPase subunit 6 and 8 ; Cyt $b$ : cytochrome b. T: incomplete stop codon.

${ }^{a}$ Numbers correspond to the nucleotides separating adjacent genes. Negative numbers indicate overlapping nucleotides.

ary structure with a stem comprised of $10 \mathrm{bp}$ and a loop of $10 \mathrm{bp}$. The secondary structures of the origin of light strand replication $\left(\mathrm{O}_{\mathrm{L}}\right)$ for 19 cryptodiran turtles (Figure 2) shows that the $\mathrm{O}_{\mathrm{L}}$ sequence nucleotides are rather conserved and the secondary structures of these sequences are also similar because 9 bp are identical in the stems, possibly a common characteristic of cryptodiran turtles.

We found that the $C$. atripons D-loop control region was 981 bp long, $69.52 \% \mathrm{~A}+\mathrm{T}$ rich and flanked by tRNA ${ }^{\text {Pro }}$ and tRNA ${ }^{\text {Phe }}$ genes (Table 2). A comparison of the complete control region sequences of four geoemydid turtles is given in the online edition of this paper (Figure S1), Similar to three other geoemydid turtles, three conserved sequence

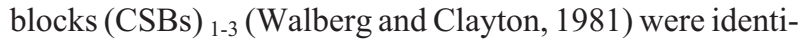
fied in the $C$. atripons control region. The whole lengths of four control region sequences ranged from $981 \mathrm{bp}$ in $C$. atripons to 1,379 bp in Cuora aurocapitata, mainly resulting from sequences positioned at the 3' end. Interestingly, a large number of AT enriched tandem repeats containing variable number tandem repeats (VNTRs) were revealed at the 3' end (right domain) of the control regions. Furthermore, the composition and number of these tandem units were different for the different species, with the $C$. atripons VNTR being composed of fifteen 5'-A (AT) ${ }_{3}$-3' units (Figure $\mathrm{S} 1$ ).

The control region is usually considered to be the most variable parts of mtDNAs in terms of nucleotide substitutions, short insertions/deletions and VNTRs dynamics. However, these variations are not distributed randomly across the whole region but occur in particular hypervariable sites and domains at the 5' and 3' ends ( $\mathrm{Su}, 2005)$.
Previous studies of turtles utilizing control region sequences were primarily focused on the 5' end adjacent to tRNA $^{\text {Pro }}$ and several regulatory motifs (Lamb et al., 1994; Walker et al., 1997; Walker and Avise, 1998). However, at present most work focuses on the 3' end close to tRNA ${ }^{\text {Phe }}$, especially tandemly repeated sequences, including VNTRs (Serb et al., 2001). The length difference between mitochondrial genomes among species is caused mainly by the divergent tandem repeats, which are thought to be generated by strand slippage and mispairing during replication (Fumagalli et al., 1996).

Tandemly repeated control region DNA has been reported from an ever-growing number of taxa. Zardoya and Meyer (1998a) characterized six tandem repeats (containing VNTRs) in the 3' domain of the P. subrufa control region and suggested that this sequence might be a potentially informative molecular marker for population studies by its unique localization in the maternally inherited mitochondrial molecule. What is remarkable is that the tandem repeats are present in the four geoemydid turtles discussed in our present paper. The repeat consists of two different repeat cores, "ATTATATC" followed by "AT" in Pyxidea mouhtii (DQ659152) than the one "A (AT) 3 " in $C$. atripons; in C. reevesii (AY676201) it is over ten 5'-ATATATC-3' units succeeded by AT-rich repeat; whereas in C. aurocapitata (AY874540) an approximately 490 bp AT-rich repeat is in the 3' of the CR, with only a few "G" nucleotides and no "C" nucleotide.

In the mitochondrial genomes of $C$. atripons and other turtles, AT enriched tandem repeats (containing VNTRs) reflect heteroplasmy, suggesting interspecies 


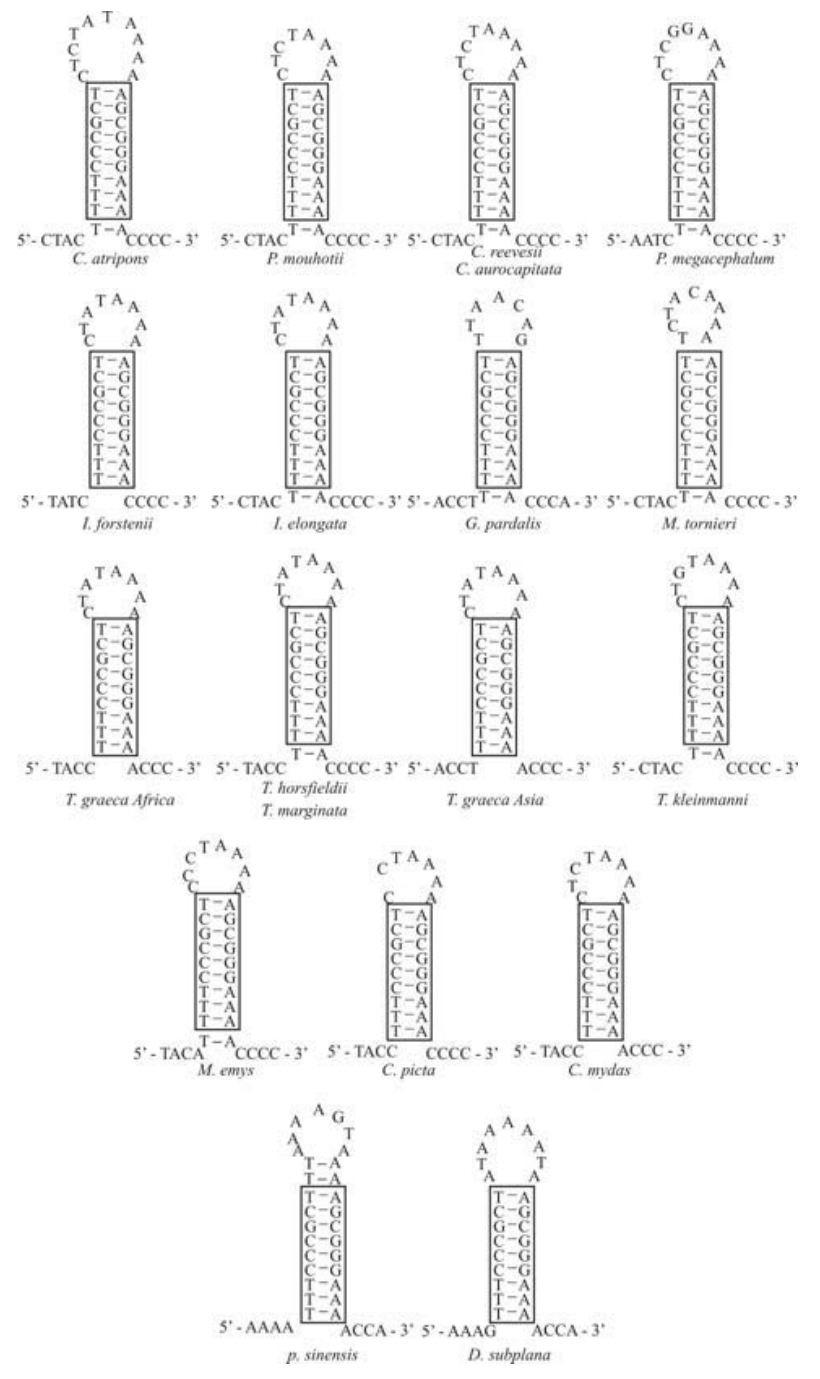

Figure 2 - Proposed secondary structures for the origins of the light strand replication $\left(\mathrm{O}_{\mathrm{L}}\right)$ of 19 cryptodiran turtles. Frames show nine identical base pairs in the stems. C. atripons: Cyclemys atripons; P. mouhotii: Pyxidea mouhotii; $C$. reevesii: Chinemys reevesii; $C$. aurocapitata: Cuora aurocapitata; P. megacephalum: Platysternon megacephalum; I. forstenii: Indotestudo forstenii; I. elongata: Indotestudo elongata; G. pardalis: Geochelone pardalis; M. tornieri: Malacochersus tornieri; T. graeca: Testudo graeca; T. horsfieldii: Testudo horsfieldii; T. marginata. Testudo marginata; T. kleinmanni: Testudo kleinmanni; M. emys: Manouria emys; C. picta: Chrysemys picta; C. mydas: Chelonia mydas, P. sinensis: Pelodiscus sinensis; D. subplana: Dogania subplana.

turtle genetic diversity. The occurrence of tandemly repeated mtDNA in the control region could be regarded as a special molecular marker in turtle species researches. However, to confirm this issue and the presence or absence of variation between specimens of the same species (intraspecies polymorphism) more informative characters need to be obtained from more turtle species and specimens. Taken as a whole, our study highlights the need for further work focusing on the 3' domain of the mitochondrial control region.

\section{Acknowledgments}

This research was supported by the National Natural Science Foundation of China (grant number 30770296), the Natural and Science Key Project of Anhui Education Department (grant number KJ2007A022) and the Key Laboratory of Biotic Environment and Ecological Safety of Anhui province. We thank three anonymous reviewers and the technical editor for critically reviewing the manuscript.

\section{References}

Fumagalli L, Taberlet P, Favre L and Hausser J (1996) Origin and evolution of homologous repeated sequences in the mitochondrial DNA control region of shrews. Mol Biol Evol 13:31-46.

Guicking D, Fritz U, Wink M and Lehr E (2002) New data on the diversity of the Southeast Asian leaf turtle genus Cyclemys Bell, 1834. Molecular results (Reptilia, Testudines, Geoemydidae*). Faunist Abh Staatl Mus Tierkunde Dresden 23:75-86.

Iverson JB (1992) A Revised Checklist with Distribution Maps of the Turtles of the World. Privately printed, Richmond, 363 pp.

Lamb T, Lydeard C and Gibbons JW (1994) Molecular systematics of map turtles (Graptemys), a comparison of mitochondrial restriction site $v s$. sequence data. Syst Biol 43:543-559.

Lamb T, Avise JC and Gibbons JW (1989) Phylo-geographical patterns in mitochondrial DNA of the desert tortoise (Xerobates agassizi), and evolution relationships among the North American gother tortoise. Evolution 43:76-87.

Mindell DP, Sorenson MD and Dimcheff DE (1998) An extra nucleotide is not translated in mitochondrial ND3 of some birds and turtles. Mol Biol Evol 15:1568-1571.

Mindell DP, Sorenson MD, Dimcheff DE, Hasegawa M, Ast JC and Yuri T (1999) Interordinal relationships of birds and other reptiles based on whole mitochondrial genomes. Syst Biol 48:138-152.

Parham JF, Feldman CR and Boore J (2006) The complete mitochondrial genome of the enigmatic bigheaded turtle (Platysternon), description of unusual genomic features and the reconciliation of phylogenetic hypotheses based on mitochondrial and nuclear DNA. BMC Evol Biol 6:11.

Parham JF, Macey JR, Papenfuss TJ, Feldman CR, Türkzan O, Polymeni R and Boore J (2006) The phylogeny of Mediterranean tortoises and their close relatives based on complete mitochondrial genome sequences from museum specimens. Mol Phylogenet Evol 38:50-64.

Peng QL, Nie LW and Pu YG (2006) Complete mitochondrial genome of Chinese big-headed turtle, Platysternon megacephalum, with a novel gene organization in vertebrate mtDNA. Gene 380:14-20.

Peng QL, Pu YG, Wang ZF and Nie LW (2005) Complete mitochondrial DNA sequence of Chinese softshell turtle (Pelodiscus sinensis). Chin J Biochem Mol Biol 21:591596.

Pu YG, Peng QL, Wang ZF and Nie LW (2005) Sequence and organization of the complete mitochondrial genome of the Chinese three-keeled pond turtle (Chinemys reevesii). Acta Zool Sin 51:691-696. 
Sambrook J and Russell DW (2001) Molecular Cloning, A Laboratory Manual. 3rd ed. Cold Spring Harbor Laboratory Press, New York.

Serb JM, Phillips CA and Iverson JB (2001) Molecular phylogeny and biogeography of Kinosternon flavescens based on complete mitochondrial control region sequences. Mol Phylogenet Evol 18:149-162.

Spinks PQ, Shaffer HB, Iverson JB and McCord WP (2004) Phylogenetic hypotheses for the turtle family Geoemydidae. Mol Phylogenet Evol 32:164-182.

Su Y (2005) Conserved and heteroplasmy on mitochondrial DNA control region in animal. Sichuan J Zool 24:669-672.

Thompson JD, Gibson TJ, Plewniak F, Jeanmougin F and Higgins DG (1997) The clustalx windows interface: Exible strategies for multiple sequence alignment aided by quality analysis tools. Nucleic Acids Res 24:4876-4882.

Walker D, Nelson WS, Buhlmann KA and Avise JC (1997) Mitochondrial DNA phylogeography and subspecies issues in the monotypic freshwater turtle (Sternotherus odoratus). Copeia 1997:16-21.

Walker D and Avise JC (1998) Principles of phylogeography as illustrated by freshwater and terrestrial turtles in the southeastern United States. Annu Rev Ecol Syst 29:23-58.

Walberg MW and Clayton DA (1981) Sequence and properties of the human KB cell and mouse L cell D-loop regions of mitochondrial DNA. Nucleic Acids Res 9:5411-5421.

Wolstenholme DR (1992) Animal mitochondrial DNA: Structure cursor for mitochondrial genomic rearrangement. Int Rev Cytol 141:173-216.
Zardoya R and Meyer A (1998a) Cloning and characterization of a microsatellite in the mitochondrial control region of the African side-necked turtle, Pelomedusa subrufa. Gene 216:149-153.

Zardoya R and Meyer A (1998b) Complete mitochondrial genome suggests diapsid affinities of turtles. Proc Natl Acad Sci USA 95:14226-14231.

\section{Internet Resources}

Scan-SE1.21 program is available at http://lowelab.ucsc.edu/ tRNA.

EditSeq, DNAsis and BioEdit programs are available at http:// www.bioon.com/Soft/.

\section{Supplementary Material}

The following online material is available for this article:

- Figure S1. The complete control regions of four geoemydids. Dots and dashes represent the same nucleotides as Pyxidea and gaps, respectively. The potential regulatory elements (CSBs) ${ }_{1-3}$ are boxed. Shaded region designates tandem repeat sequences at the 3' end of CRs.

This material is made available as part of the online article from http://www.scielo.br.gmb.

Associate Editor: João S. Morgante

License information: This is an open-access article distributed under the terms of the Creative Commons Attribution License, which permits unrestricted use, distribution, and reproduction in any medium, provided the original work is properly cited. 
Cyclemys atripons

Chinemys reevesii

Pyxidea mouhotii

Cuora aurocapitata Cyclemys atripons

Chinemys reevesii

Pyxidea mouhotii

Cuora aurocapitata Cyclemys atripons

Chinemys reevesii

Pyxidea mouhotii

Cuora aurocapitata Cyclemys atripons Chinemys reevesii

Pyxidea mouhotii

Cuora aurocapitata Cyclemys atripons Chinemys reevesii

Pyxidea mouhotii

Cuora aurocapitata Cyclemys atripons Chinemys reevesii

Pyxidea mouhotii Cuora aurocapitata Cyclemys atripons Chinemys reevesii

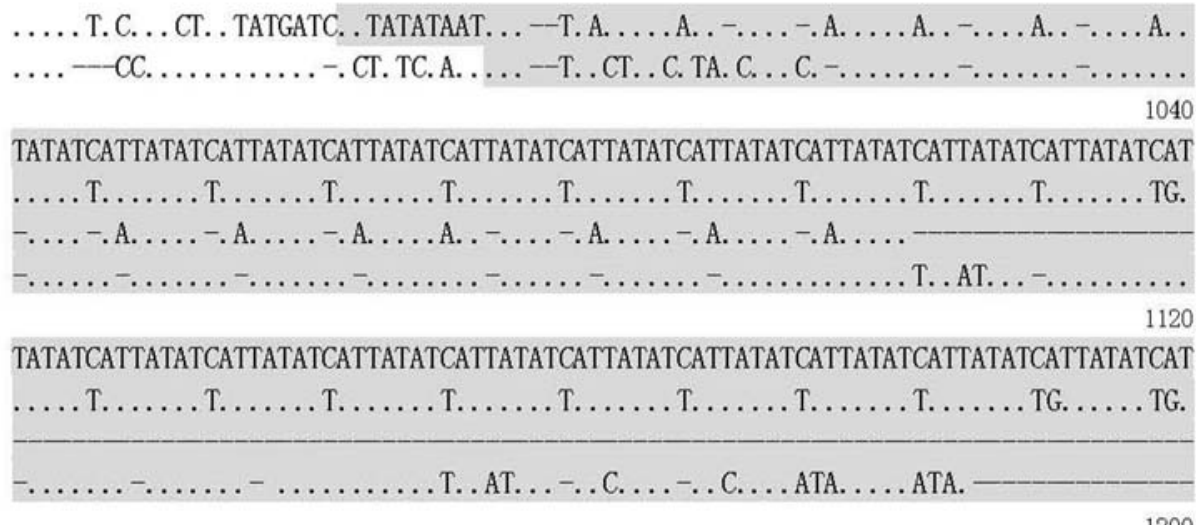

1200

TATATCATTATATCATTATATCATTATATCATTATATCATTATATCATTATATCATTATATCATTATATCATTATATCAT

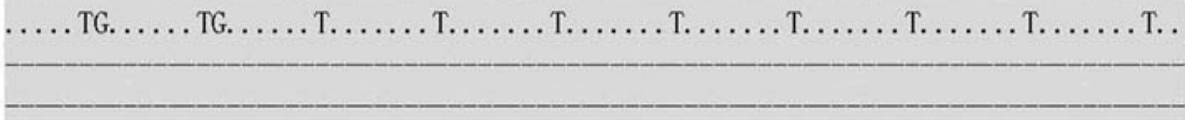

1280

TATATCATTATATTATTATATTATTATATTATTATATTATTATATTATTATATTATTATATTATTATATCATTATATCAT

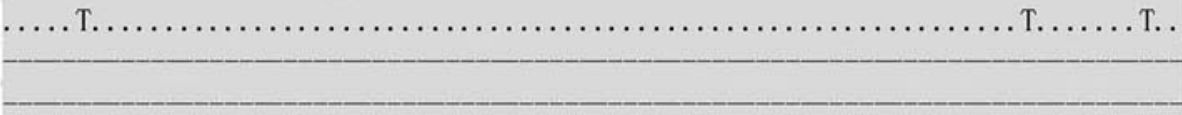

1360

TATATCATTATATTATTATATTATTATATTATTATATTATTATATTATTATATTATATTAT-AT

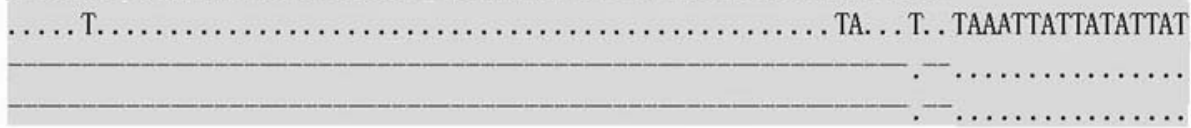

1410

TAGATTATTATATTATTATATTATTATATTATTATATTATTATATATATA 